\title{
Collaborative research to inform adaptive comanagement: a framework for the He'eia National Estuarine Research Reserve
}

\author{
Kawika B. Winter ${ }^{1,2,3,4}$, Yoshimi M. Rii ${ }^{1,2}$, Frederick A. W. L. Reppun ${ }^{1,2}$, Katy DeLaforgue Hintzen ${ }^{2,5}$, Rosanna A. Alegado ${ }^{5,6}$, Brian $^{12}$

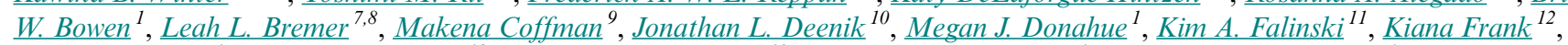 \\ Erik C. Franklin ${ }^{1}$, Natalie Kurashima ${ }^{13}$, Noa Kekuewa Lincoln ${ }^{10}$, Elizabeth M. P. Madin ${ }^{1}$, Margaret A. Mc Manus ${ }^{6}$, Craig E. Nelson \\ ${ }^{5,6,14}$, Rvan Okano $^{15}$, Anthonv Olegario $^{15}$, Pua'ala Pascua $^{16}$, Kirsten L. L. Oleson $^{3}$, Melissa R. Price $^{3}$, Malia Ana J. Rivera ${ }^{1}$, Kuulei S. \\ Rodgers $^{1}$, Tamara Ticktin ${ }^{17}$, Christopher L. Sabine ${ }^{6}$, Celia M. Smith ${ }^{17}$, Alice Hewett ${ }^{18}$, Rocky Kaluhiwa $^{19}$, Māhealani Cypher ${ }^{20}$, Bill \\ Thomas $^{21}, \underline{\text { Jo-Ann Leong }}^{1}, \underline{\text { Kristina Kekuewa }}^{22}, \underline{\text { Jean Tanimoto }}^{21}, \underline{\text { Känekoa Kukea-Shultz }}^{18}, \underline{\text { A. Hit ilei Kawelo }}^{23}, \underline{\text { Kelit i Kotubetey }}^{23}$, \\ Brian J. Neilson ${ }^{15}$, Tina S. Lee ${ }^{21,24}$ and Robert J. Toonen ${ }^{1}$
}

ABSTRACT. Globally, an increasing recognition of the importance of ecosystem-based management (EBM), Indigenous resource management (IRM), and Indigenous-led research and management is emerging; yet, case studies within scholarly literature illustrating comprehensive application of these theories and philosophies are scarce. We present the collaborative management model for the Heeia National Estuarine Research Reserve (NERR) as a contemporary Indigenous Community and Conserved Area (ICCA) that has synergistically operationalized these principles, as well as one that approaches research as a reciprocal collaboration with the Indigenous people and local community (IPLC) of place. The He'eia NERR was designated in 2017 through a process led by IPLC members in Hawai $i$. This research framework is aimed at informing EBM within social-ecological systems. It, therefore, serves as an example of a program designed to demonstrate and provide practical solutions for adaptive resource management. The framework of the Heeia NERR embraces the values, perspectives, and IRM strategies that have been foundational for the people of the Pacific to thrive sustainably in the context of limited resources for millennia. As a program, the He'eia NERR aims to build bridges between coexisting worldviews as a means of informing policy in the realms of conservation and sustainability. We do this by weaving together conventional and Indigenous science to collaboratively develop research and collaboratively produce new knowledge. We examine these issues through the lens of holistic ecosystem services that consider both the reciprocal benefits that humans provide to nature as well as the full range of existential benefits that humans gain from nature. Research collaborations between the He eia NERR and its partners (University of Hawai i, state and federal agencies, and Indigenous-led NGOs operating in the community) are grounded in Indigenous and local knowledge (ILK) with applications that will guide a future of enhanced ecosystem services in a changing world.

Key Words: ecosystem-based management (EBM); Indigenous and community conserved area (ICCA); Indigenous and local knowledge (ILK); Indigenous people and local community (IPLC); Indigenous resource management (IRM); Indigenous science; National Estuarine Research Reserve System (NERRS); reciprocal collaboration

\section{INTRODUCTION}

The conventional discourse in environmental science and conservation biology has portrayed humans as separate from nature and has depicted human actions as inherently disruptive to healthy ecosystem function (e.g., Soulé 1985, Terborgh 2004). However, these conventional notions of conservation are philosophically founded, at least in part, in racist perspectives that viewed native people as blights on nature that needed to be purged in order to attain a pristine wilderness (Kashwan 2020). These foundational philosophies have subsequently led to institutional approaches to conservation that aim to restrict human presence in an attempt to create pristine nature separate from human influence. Such an approach, however, often happens at the expense of displacing Indigenous people (Guha 1989, Nelson and Callicott 2008). Reactional approaches, such as fortress conservation, which holds that biodiversity protection is best achieved by creating protected areas in which ecosystems can function in isolation from human disturbance, serve to perpetuate the perceived need to protect nature from humanity (Wilshusen et al. 2002). Although this has been cited as a rationale for creating nature reserves across the globe, the end results of such approaches often fall short of overall conservation goals (Laurance et al. 2012, Dominguez and Luoma 2020).

In contrast to conventional thinking, disciplines such as Indigenous studies and political ecology challenge mainstream

\footnotetext{
${ }^{1}$ Hawai $i$ Institute of Marine Biology, University of Hawai i at Mānoa, ${ }^{2} \mathrm{He}$ eia National Estuarine Research Reserve, Hawai i i, ${ }^{3}$ Natural Resources and Environmental Management, University of Hawai'i at Mānoa, ${ }^{4}$ Hawai ${ }^{i} i$ Conservation Alliance, ${ }^{5}$ University of Hawai i Sea Grant College Program, ${ }^{6}$ Department of Oceanography, University of Hawai'i at Mānoa, ${ }^{7}$ University of Hawai'i Economic Research Organization, University of Hawai'i at Mānoa, ${ }^{8}$ Water Resources Research Center, University of Hawai'i at Mānoa, ${ }^{9}$ Institute for Sustainability and Resilience, University of Hawai'i at Mānoa, ${ }^{10}$ Tropical Plants and Soil Sciences, University of Hawaii i at Mānoa, ${ }^{11}$ The Nature Conservancy, Hawai i ${ }^{12}$ Pacific Biosciences Research Center, Kewalo Marine Lab, University of Hawai'i at Mānoa, ${ }^{13}$ Natural and Cultural Resources, Kamehameha Schools, ${ }^{14}$ Daniel K. Inouye Center for Microbial Oceanography: Research and Education, ${ }^{15}$ Division of Aquatic Resources, Department of Land and Natural Resources, Hawai'i , ${ }^{16}$ Center for Biodiversity and Conservation, American Museum of Natural History, New York, ${ }^{17}$ School of Life Sciences, University of Hawai i at Mānoa, ${ }^{18} \mathrm{Kāko}$ o 'Ōiwi, ${ }^{19} \mathrm{Ko}$ 'olaupoko Hawaiian Civic Club, ${ }^{20}$ Ko'olau Foundation, ${ }^{21}$ Office for Coastal Management, National Oceanic and Atmospheric Administration, Honolulu, Hawai i ${ }^{22}$ Office of National Marine Sanctuaries, National Oceanic and Atmospheric Administration, Hawai'i, ${ }^{23}$ Paepae o He'eia, ${ }^{24}$ Lynker LLC
} 
conservation strategies by centering people as an inseparable part of nature (Escobar 1998, McGregor et al. 2003, Adams and Hutton 2007, Berkes 2018). Indigenous peoples have histories spanning millennia across a vast majority of Earth and have managed landscapes that allowed human societies and nature to thrive together (Denevan 1992, Zimmerer 2006, Robbins et al. 2015, Garnett et al. 2018). Though our current geological age, the Anthropocene, is defined as beginning when the collective activities of humans influenced earth systems (Crutzen 2006, Lewis and Maslin 2015), and the global market economy is the primary contributor to anthropogenic climate change (IPCC 2018), it is critical to acknowledge that not all human activity negatively affects biodiversity and ecosystem function; Indigenous peoples being the prime example of that alternative notion (Berkes 2018, Winter et al. 2020a). Many Indigenous resource management (IRM) strategies and practices are intended to enhance ecosystem processes (e.g., productivity) and services, including biodiversity and species abundance, as a means to increase system resilience (Berkes 2018, Winter et al. 2020a). Therefore, Indigenous peoples and local communities (IPLCs) that perpetuate these practices provide valuable examples for examination (Ban et al. 2018, Eckert et al. 2018, Howitt 2018). Additional research into such approaches can inform policy and management actions to meet contemporary challenges.

Conservation and sustainability policies are often contextualized in terms of ecosystem services, yet that framing has been criticized for depicting a one-way flow of benefits to humans and for characterizing human-nature interactions as transactional (Schröter et al. 2014). Rather than abandon the ecosystem services framework, we advocate for a more holistic and relational definition of ecosystem services that acknowledges reciprocal human-nature relationships and encompasses the full range of existential benefits, such as cultural, psychological, physiological, spiritual, aesthetic, recreational, socioeconomic, and natural aspects (Pascual et al. 2017). Adopting a holistic approach aligns with other comprehensive views that describe the reciprocal relationships between people and ecosystems, as embraced by various cultures, IPLCs in particular (Comberti et al. 2015, Winter $2020 a$ ), and with scholarship advocating for a more dynamic view of ecosystem services in multiple decision-making policy arenas (cf. Chan et al. 2016, Pascua et al. 2017, Díaz et al. 2019). Furthermore, a more holistic interpretation of ecosystem services provides a viable lens through which we can examine both conservation (e.g., habitat loss and extinction) and sustainability (e.g., food and energy systems, and climate adaptation) issues, as well as their interactions. With this intersection in mind, much remains to be learned from the cultural paradigms of isolated island cultures, societies, and civilizations who either thrived or failed, in the context of bounded resources and invasive species, based on the sustainability of their management practices. Examples of sustainable island management practices in this context include Rapa Nui (Hunt and Lipo 2011) and Hawai'i (Abbott 1992, Jokiel et al. 2011, Kurashima et al. 2019), the latter being the focus of this paper.

Over the past forty years, considerable effort has been undertaken to restore the health and function of Hawaiian social-ecological systems (IUCN 2016, Chang et al. 2019a, Winter et al. 2020a). These efforts have been undertaken by local communities reclaiming agency over Indigenous legacy lands and reestablishing their connections to the land in the face of urbanization (McGregor-Alegado 1980, Goodyear-Ka'ōpua et al. 2014, Kubota 2018). More recently, applied research on diverse topics such as habitat and biodiversity protection (Friedlander et al. 2002, Jokiel et al. 2011, Burnett et al. 2018), core watershed function (Winter and Lucas 2017), agroecology (Lincoln et al. 2018, Winter et al. 2018a, Kurashima et al. 2019), aquaculture (Summers 1964, Kikuchi 1976, Costa-Pierce 2008), fisheries management (Poepoe et al. 2003), coral reef health (Bahr et al. 2015), community engagement (Matsuoka et al. 1998), and Indigenous resource management (Kurashima et al. 2018, Winter et al. 2018a,b) have supported such community efforts.

Despite the growing body of research and local-level examples demonstrating the viability of human-in-nature approaches to conservation, policies at multiple levels of government have yet to fully embrace this approach (Sterling et al. 2017). Thus, collaborative partnerships between resource managers and researchers are necessary to conduct applied research (Gavin et al. 2018). In Hawai' $i$, collaborative partnerships can inform policies guiding the restoration and adaptive management of Hawaiian social-ecological systems (sensu Winter et al. 2018b) in the context of these modern challenges (Ayers et al. 2018). The Hawaiian concept of 'āina momona (Kamakau 1976, Andrade 2008), meaning a state of sustainable resource abundance, has increasingly become central to this discussion (Chang et al. 2019a, b).

\section{Contextualizing ecosystem-based management research within} Hawaiian social-ecological systems

Like other Pacific Island cultures, Hawaiian society developed IRM norms centered on natural resource limitations inherent to living on high volcanic islands (Fisher 2015). Seminal publications in the realm of Hawaiian IRM have synthesized the broad array of Native Hawaiian authors who documented Indigenous philosophies and practices in the Hawaiian language during the 19th and 20th centuries (Handy et al. 1992, Maly and Maly 2003). These works highlight foundational elements of Hawaiian IRM, such as the inseparable connection between people and place, the connection between the mountains and the sea, the importance of stratified land divisions that facilitate decentralized resource management, and the roles that sacred designations of places and species played in ensuring a sustainable abundance of resources. Hawaiian IRM (hereafter, Hawaiian resource management) adaptively managed the population dynamics and connectivity of key resource species at the habitat level (Winter et al. 2018b), and employed various forms of ecomimicry (sensu Winter et al. 2020a) such as habitat engineering in agroecology systems, which mimics natural disturbance regimes to increase the productivity within landscapes, to attain the state of 'aina momona. The Hawaiian civilization that persisted under this system was one of the resource-bound, island societies documented to live sustainably for centuries while maintaining a large human population (Kittinger et al. 2011, Bahr et al. 2015, Winter et al. 2018a), even in the face of geometric population growth (Dye and Komori 1992).

Notably, there is no evidence of significant decline in marine resources throughout the centuries preceding colonization 
(Kittinger et al. 2011). Occasional famine has been noted in the precolonial period and linked to temporary climatic shifts (Dye and Komori 1992, Chinn et al. 2014, Winter et al. 2018b). Local declines in fish stocks were, however, documented during the colonial period. For example, severe deficiency of fish observed in the 19th century was attributed to ineffective management (Ellis 2004). Cumulatively, these data suggest that states of resource abundance can be tenuous and susceptible to unpredictable changes in environment, and further that careful management of resources is required to prevent overharvest, and to persist through and rebound from episodic changes in climate. In contrast to the vast majority of the prior millennium, in which 1.2 million people could have been sustainably fed without imported resources (Abbott 1992, Kurashima et al. 2019), Hawai'i's current population of 1.4 million people imports over $90 \%$ of its food, a notably unsustainable scenario (Jokiel et al. 2011, Loke and Leung 2013). This supports the notion that much can be learned from Indigenous and local knowledge (ILK) when it comes to sustainability in the context of limited resources.

Over the past 150 years, market-based approaches to resource management, born from a worldview that sees humans as separate from nature, have replaced the island-adapted practices of an IRM model that is based on the relationship between people and place (Winter et al. 2018b). This period coincided with substantial declines in ecosystem services (e.g., abundance of key resource species) that are most obvious around urban population centers (Jokiel et al. 2011); a trend observed throughout the Pacific region (Johannes 1978). The observable decline in ecosystem services, experienced over the lifetimes of individuals raised in the tradition of 'āina momona, has prompted many community-based groups to revitalize IRM and re-establish it as a solution to issues of sustainability (Minerbi 1999, 2001, Andrade 2008). This has been tangibly accomplished by creating contemporary Indigenous and community conserved areas (ICCAs; sensu Berkes 2009a) that are supported by collaborative management agreements with government agencies (e.g., Delevaux et al. 2018). In these continuing efforts, communities seek to learn from the past to better manage natural resources. Thus, the global movement toward ecosystem-based management (EBM; Rodriguez et al. 2011) is particularly welcome and familiar among Pacific Islanders, who have managed resources accordingly to thrive within social-ecological systems for millennia (Winter et al. 2020a). The basic premises of EBM are to: prioritize the health and function of the entire ecosystem over the needs of any individual activity or special interest group; be place-based with natural boundaries; account for multiple interactions, and how human actions both within and outside the place can influence or be influenced by management; integrate the concerns of the environment, society, economy, and human institutions; consider humans as part of the system and maintain access to the broad array of ecosystem services; and provide a mechanism for participation and coordination among all responsible entities (McLeod and Leslie 2009). Despite widespread consensus on the general tenets of EBM, questions remain about what exactly constitutes EBM as an explicit adaptive management strategy to increase a holistic set of ecosystem services. This has presented challenges for the attempts to create policy that supports the implementation of EBM through existing governance and economic structures (Levin and Möllmann 2015, Prellezo and
Curtin 2015). The goal of this concept paper is to establish a framework for the collaborative development of research and the subsequent collaborative production of new knowledge that can inform policy and practice regarding adaptive EBM in Hawai' $i$ and beyond, using the He'eia National Estuarine Research Reserve (NERR) as an illustrative case.

\section{On language and terminology}

Globally, Indigenous languages play an important role in biodiversity conservation (Maffi 2005, Gorenflo et al. 2012, Wilder et al. 2016). The same is true in Hawai' $i$ where Hawaiian language terms are essential to discussions around IRM and EBM to convey nuances in meaning to IPLCs that are not sufficiently characterized by English language translations. For example, although the Hawaiian word pono lacks a suitable direct English language translation, pono can be interpreted as referring to actions that are appropriate, correct, balanced, and deemed necessary by traditional standards in the Hawaiian culture (Gould et al. 2019). Hawaiian language terminology is increasingly being incorporated within collaborative management plans and policies between Native Hawaiians and both federal and state agencies (e.g., the Papahānaumokuākea Marine National Monument Management Plan). The He'eia NERR also uses Hawaiian terminology in reference to Indigenous perspectives and management practices to convey those nuances, and is committed to doing so in a way that honors the terminology and that protects against cultural appropriation meant to suit outside interests. The He'eia NERR research framework, therefore, requires some working knowledge of a Hawaiian worldview and of traditional standards in Hawaiian culture.

Furthermore, the words tradition/traditions/traditional are used herein to refer to customary cultural norms and values in Hawai i, and the traditional and customary practices of Native Hawaiians protected in the state constitution and other bodies of law (Akutagawa et al. 2016a, b). Although we recognize the history associated with such terminology and its use as tools of colonization to inhibit the evolution of Indigenous cultures, in Hawai $i$, it is currently the commonly accepted terminology among IPLC members. We use this terminology where appropriate while acknowledging that traditional practices are adaptive and evolve over time.

\section{Collaborative management in the He'eia National Estuarine Research Reserve}

Comanagement efforts between IPLCs and government agencies have not always been successful, especially where government agencies have imposed designations that restricted human activity first, and then attempted to engage IPLCs in comanagement as a secondary process. Examples of this are some Marine Protected Areas (MPAs) and National Parks (Coombes and Hill 2005, Singleton 2009, Ross et al. 2011). However, there is a range of comanagement approaches that includes "cooperative management," "community-based management," and "collaborative management," with each iteration existing on a scale of a power differential between communities and government. Of these, we advocate for collaborative management that empowers IPLCs, and that mutually honors both Indigenous and conventional knowledge systems and approaches (Tipa and Welch 2006). This form of comanagement has long-been recognized as an effective approach to conservation and sustainability (Carlsson and Berkes 2005, 
Berkes 2009b). The long-term success of collaborative management arrangements, however, relies heavily on the design process; for instance, recognizing the importance of free, prior, and informed consent from IPLCs in advance of implementing human activity regulations or restrictions, and ensuring that equitable collaborative management is indeed a primary goal of the management area.

In He'eia, on O'ahu Island, Hawai'i, in the context of a larger Hawaiian renaissance (Gon and Winter 2019), an Indigenous-led contingent set out to engage government entities to support the creation of a contemporary ICCA through a collaborative management agreement. Native Hawaiian elders ( $k \bar{u}$ puna) and other community leaders advocated for a collaborative management model that would support the IPLC's interests, and they selected the National Estuarine Research Reserve System (NERRS) as the one best structured for those purposes (Hawai' $i$ Office of Planning 2016). The NERRS is a network of coastal sites designated to protect and study estuarine systems, established through the Coastal Zone Management Act. Each reserve is collaboratively managed by a state agency that acts as a program administrator, and the Office for Coastal Management (OCM) within the National Oceanic and Atmospheric Administration (NOAA). Unlike NOAA's sanctuary designation, a type of MPA which typically identifies no-take marine protected areas, the reserve designation does not necessarily regulate human activity within its reserve boundaries. Rather, it is a collaborative management arrangement that operates within existing state laws and local ordinances. The He'eia NERR is unique in the national system specifically because its designation process was IPLC driven and was undertaken to support an existing ICCA. It, therefore, represents a true collaborative management effort that engages the IPLC of place rather than one that is limited to an agreement between federal and state governments.

The He'eia NERR was designated in Hawai'i in 2017 as the 29th reserve in the national system, with the state partner being the University of Hawai 'i at Mānoa (UHM). The University of Hawai'i system, as a designated Land Grant, Sea Grant, and Space Grant Institution, has a committed responsibility to public service and outreach. The He'eia NERR, as a part of that system, operates within this context. It has no regulatory purview over land or sea itself, but its site partners have committed to collaboratively managing this area, which covers 560 hectares (1385 acres; Fig. 1). The Reserve is organizationally administered through the Hawai'i Institute of Marine Biology (HIMB), which itself is a part of UHM's School of Ocean and Earth Science and Technology (SOEST). The He'eia NERR is physically located in the region of Ko'olaupoko, in a place traditionally called Kawaha-o-ka-manō, but now commonly referred to as Kāne’ohe Bay. There are several ecosystem-scale habitats (including forests, streams, wetlands, riparian areas, an estuary, and coral reefs) within the He'eia NERR boundaries. The reserve is situated within a community of mixed human demographics with more than two-thirds of these being IPLC residents born in Hawai i. This local community is composed mainly of Native Hawaiians and the descendants of immigrants from Western Europe, North America, and the Asia-Pacific region (Hawai'i Office of Planning 2016).
Native Hawaiian self-governance is not legally recognized by either federal or state governments, but the He'eia NERR has designed pathways for Native Hawaiians to participate in the governance of the reserve. Native Hawaiian representation in the collaborative management agreement is formally held by Hawaiian-led, nonprofit organizations operating within the larger region, and those who demonstrate their management authority through active stewardship practices within the boundaries of the reserve specifically. This collaborative management agreement exists between the seven entities who led the designation process for the reserve (Table 1), each of whom is now recognized as an official collaborative management partner and plays a role in the reserve governance via a seat on the reserve's advisory board. Although not a resource managing entity in and of itself, the He'eia NERR facilitates collaborative management among its site partners and provides support for restoration efforts. Its role within this context is to lead and conduct research in collaboration with the IPLC of He'eia in a larger effort to inform adaptive comanagement among the site partners in the reserve. There are several examples from around the globe of IPLCs participating in collaborations aimed at better understanding how ILK, along with ancestral perspectives, technologies, and practices, can contribute to solving various problems that threaten the health, function, and resilience of the social-ecological systems in which they live (Kirkness and Barnhardt 2001, CIDA 2002, Fisher and Ball 2003, ISE 2006, Berkes 2009b, CTKW 2014, Smith 2015). The He'eia NERR serves as a model of such a collaboration, with its designation process being led by the IPLC of the associated place. Salient issues in the overlapping realms of conservation and sustainability have been at the forefront of these collaborations. The various outputs of He'eia NERR will contribute to a growing body of knowledge about adaptive comanagement across the United States and around the world.

Fig. 1. The boundaries of the He'eia National Estuarine Research Reserve (NERR) in the region of Ko'olaupoko on the Island of $\mathrm{O}^{`} \mathrm{ahu}$.

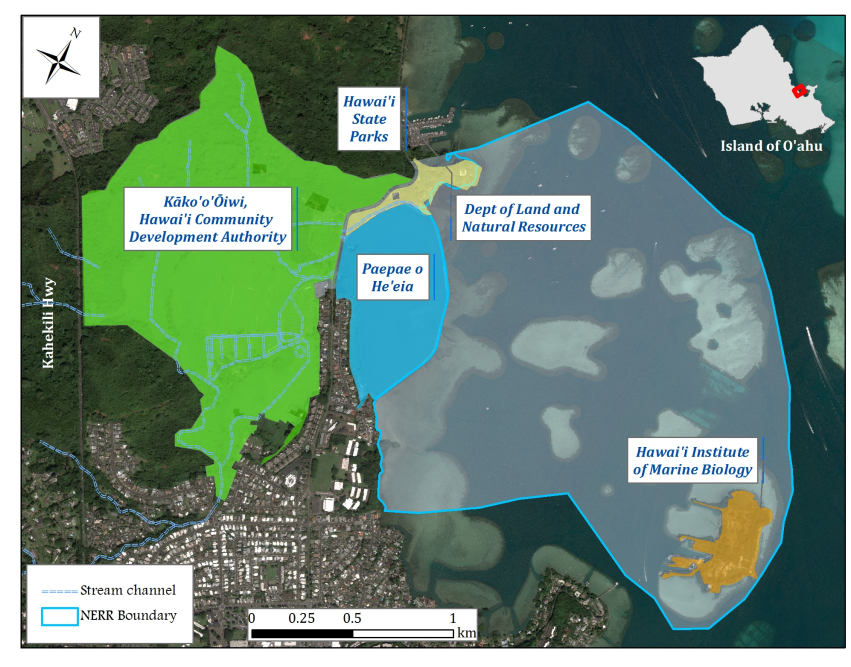


Table 1. The seven collaborative management partners of the He'eia National Estuarine Research Reserve and their respective organizational classifications. Each of these site partners holds a seat on the He'eia NERR's Advisory Board, and thus plays a role in the reserve's governance.

\begin{tabular}{lll}
\hline \hline Collaborative management partner & Organizational classification & Focus and scope \\
\hline Ko'olaupoko Hawaiian Civic Club & Hawaiian-led, nonprofit organization & Civic engagement within the region \\
Ko'olau Foundation & Hawaiian-led, nonprofit organization & Community-based efforts within the region \\
Kāko'o ‘Ōiwi & Hawaiian-led, nonprofit organization & Restoration of sustainable Indigenous agro-ecology in the reserve \\
Paepae o He'eia & Hawaiian-led, nonprofit organization & Restoration of sustainable Indigenous aquaculture in the reserve \\
Hawai'i Institute of Marine Biology & Research unit of University of Hawai'i at & Research and training in tropical marine biology, biodiversity, and \\
(HIMB) & Mānoa (UHM) & conservation (physically located within the reserve) \\
Department of Land and Natural & Agency within the State of Hawai'i & Management (rules, regulations, and enforcement) of lands and \\
Resources (DLNR) & government & waters outside of urban, residential, and agricultural areas \\
Hawai'i Community Development & Public entity created by the Hawaíi State & Establishes plans for community development districts (holds the \\
Authority (HCDA) & Legislature & title to the land upon which Kāko'o 'Ōiwi operates) \\
\hline
\end{tabular}

\section{A FRAMEWORK FOR COLLABORATIVE RESEARCH IN HE'EIA}

\section{Contextualizing He'eia NERR's collaborative research framework}

In the inaugural phase of the He'eia NERR, the fundamental question for its research program is: What are the most effective EBM strategies that contribute to the resilience and integrity of estuarine ecosystems considering anthropogenic drivers in the context of sociocultural and environmental factors? This question can be addressed by assessing a suite of ecosystem services. Research stemming from this question must weave modern technologies, tools, and information together with ancestral ones based on deep and ancient ties to the 'âina (land) and born from Indigenous science that is encoded within ILK. We seek creative and collaborative research and management strategies to return food security, resilience, and sustainable resource stewardship to the hands of the community, thereby serving as an example of effective EBM in the twenty-first century.

However, the aspirations of the He'eia NERR are contextualized against the challenges and conflicts between IPLCs and researchers in Hawai i (e.g., Alegado 2019), which are similar to those experienced by other IPLCs around the world. Accordingly, the He'eia NERR's research framework and associated guidelines align, in many ways, with both the letter and the spirit of those produced previously for researchers working with IPLCs (e.g., Kirkness and Barnhardt 2001, CIDA 2002, Fisher and Ball 2003, ISE 2006, CTKW 2014, Smith 2015) in that they honor the rights of Indigenous people and the perspectives of IPLCs. Although the context for the genesis of the He'eia NERR's framework shares similarities with place-based programs in other parts of the world, it contains some things not found in all IPLCs. For instance, as may be the case in many other IPLCs, Indigenous self-governance in Hawai' $i$ is complicated by centuries of colonization, including the illegal overthrow of the Hawaiian Kingdom in 1893 and subsequent ramifications (Beamer 2014). As a result, there is no legally recognized, sovereign Indigenous entity representing Native Hawaiians and there are no nation-tonation agreements like those that exist in other places. That said, certain Native Hawaiian rights still exist as originally codified under the Kingdom of Hawai i. For instance, traditional and customary practices and the lands and waters on which they depend are protected by the State of Hawai i Constitution and have been repeatedly reaffirmed by precedent set in case law (e.g., Akutagawa et al. 2016a, $b$ ). This provides a strong rationale for collaborative management and a collaborative research framework. Furthermore, the decades-long Hawaiian Renaissance (Chang et al. 2019a, Gon and Winter 2019) has resulted in new generations of graduate-level IPLC researchers in the biological, physical, and social sciences. This has allowed IPLC researchers to influence how research is conducted from within institutions, whether it be universities, government agencies, or nongovernmental organizations. The establishment of the He'eia NERR and this associated concept paper itself are notable achievements of that movement because they represent changes in policy and action that have resulted from doing work with IPLCs rather than within them (Smith 2013).

Accordingly, the goal of the He'eia NERR is to practice and promote responsible stewardship through collaborative management in manners that are consistent with Native Hawaiian values. It also conducts innovative research, in collaboration with its collaborative management partners, to contribute to broader understandings of sustainable ecosystem-based management within social-ecological systems. As such, the He'eia NERR aims to examine the effects of two fundamentally different management strategies relating to ecosystem services: (1) conventional ecological restoration techniques developed out of contemporary study of biological sciences in the modern era; and (2) IRM strategies informed by ILK (including Indigenous science) along with associated philosophies and practices. Both strategies seek to integrate concerns about the environment, society, economy, and human institutions, but focus on different aspects. In the former, ecological restoration is typical of contemporary conservation projects in which the primary goal is to restore a damaged or degraded ecosystem to a pre-existing state by using prehuman conditions as the starting point for restoration design (SER 2004). However, this strictly ecological focused approach, often advocated for by government agencies, falls short of the full tenets of EBM, which requires explicit consideration of humans as part of the ecosystem. Furthermore, this strictly ecological approach tends to lead to conflict between conservationists and IPLC members. The strategies associated with Hawaiian social-ecological systems, which characterizes the latter, are part of an EBM approach employed for centuries prior 
Fig. 2. Schematic showing He'eia NERR's reciprocal collaboration process for researchers proposing a research project with Indigenous peoples and local communities (IPLC). Before proposing a project, researchers must develop a relationship with He'eia by engaging in restoration and work days. Then together with the IPLC, researchers must align their research interest/question with the needs and issues prioritized by the IPLC. Iterative feedback is crucial during and after the project through regular knowledge exchange meetings and Coastal Training Program (CTP) workshops to inform products and management strategies. Outputs and products will be IPLC-led and seek to protect Indigenous intellectual property.

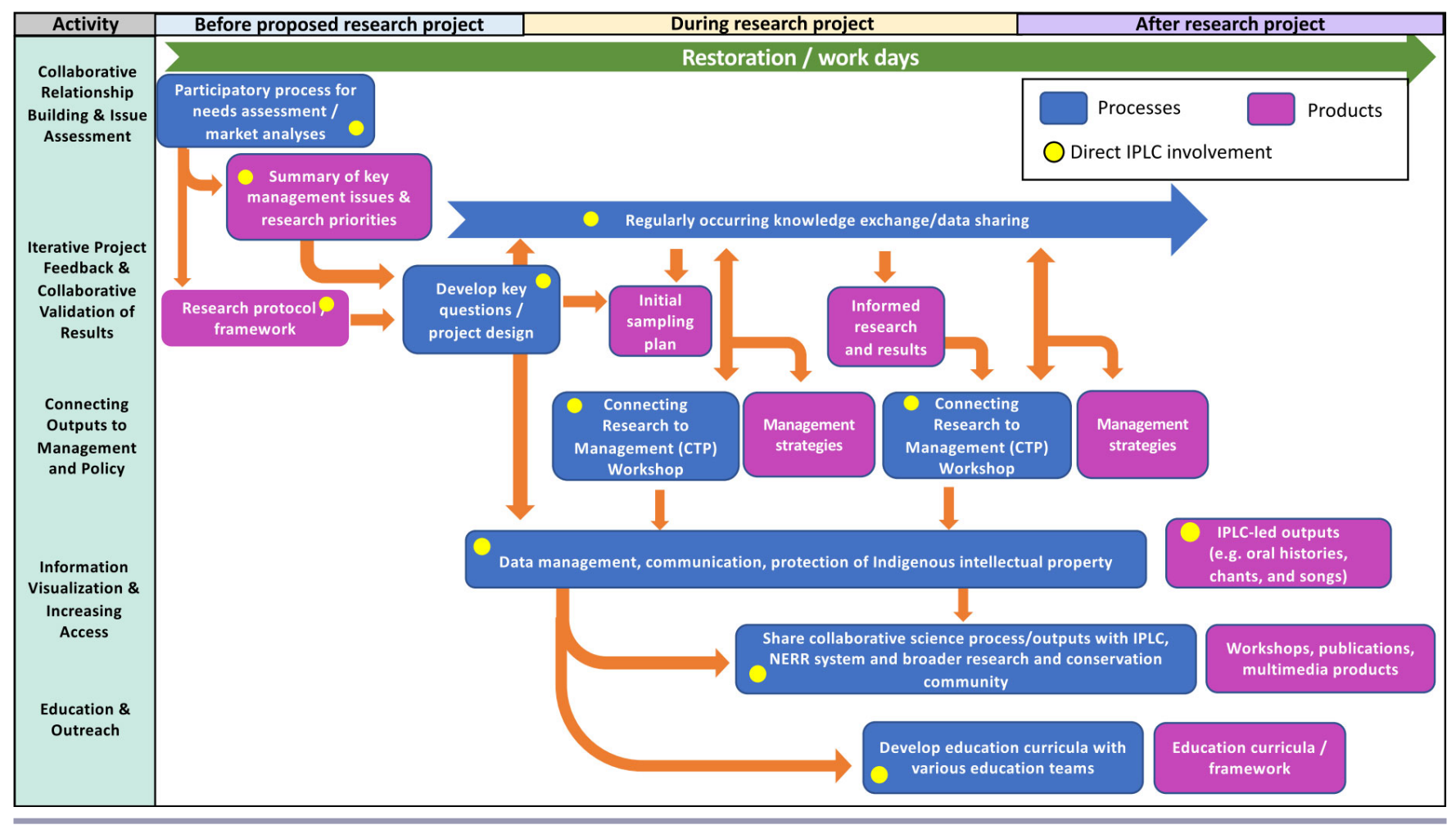

to European contact (Jokiel et al. 2011, Bahr et al. 2015). The essential premise of this approach is to manage resources in a manner that optimizes multiple ecosystem services (defined holistically) in the context of a reciprocal relationship between people and nature (Winter et al. 2020a), which are encapsulated in Native Hawaiian values.

\section{A values-based design for reciprocal collaboration in research}

Researchers often aim to engage ILK held in IPLCs for various reasons (Tengö et al. 2017). However, collaborative studies initiated with and by IPLC members (i.e., in mutual agreement between researchers and IPLC members) can more effectively engage ILK than studies initiated by researchers alone (Smith 2013, Ban et al. 2018, David-Chavez and Gavin 2018, Kūlana Noi'i Working Group 2018). Reciprocal collaboration is a viable pathway for researchers to engage with IPLCs. Reciprocal collaboration has been defined as the ability to share ideas and perspectives in an open and trusting environment in which common goals are created through a collaboratively generated process (Johnson 2008). We add that reciprocal collaboration is also purposefully designed to be mutually beneficial to both researchers and the IPLC of place. However, any discussion of a research framework for reciprocal collaboration must be prefaced by ethical practices and values rooted in the Indigenous and local cultures of the area, with reciprocity and equity in mind (Kūlana Noi'i Working Group 2018). The Native Hawaiian community's sense of kuleana, to promote relationships to place and resilience of place, is held strongly. A sense of kuleana also exists regarding the revitalization of traditional and customary practices in an effort to restore and maintain a state of 'àina momona. Thus, there are broad community and policy interests in sustainable resource management. Therefore, the He'eia NERR research program seeks to learn from and inform individual and collective kuleana, and to inform policy as it relates to adaptive management strategies for healthy and sustainable social-ecological systems. However, guiding principles for doing so are needed.

\section{Guiding principles for a research framework centered on reciprocal collaboration}

A fundamental goal of the He'eia NERR is to engage in reciprocal collaboration with the IPLC of the Ko'olaupoko region in a manner that equitably benefits both the community and researchers by recognizing and seeking to correct power disparities. Such an approach necessitates a pono framework for engaging in collaborative management and conducting collaborative research (Berkes 2009c, Bennett et al. 2019) within the designated boundaries of He'eia NERR (Fig. 1) and within the larger region of Ko'olaupoko. In this regard, research 
conducted within and/or otherwise supported by the He'eia NERR should align with the priorities of the IPLC, and it should operate within a process deemed pono by the community. The He'eia NERR's framework for reciprocal collaboration, therefore, is built on a fundamental question and consists of a set of guiding principles for collaborative endeavors between researchers and IPLCs. This framework includes a list of research priorities identified by the community (see our reciprocal collaboration process for researchers and IPLC before, during, and after a proposed research project; Fig. 2).

Equally important are culturally attuned processes of acquiring free and informed consent prior to initiating research projects (cf. FAO 2016, Kūlana Noi'i Working Group 2018). A general framework for research standards in Hawai'i, "Kūlana Noi'i i" (Kūlana Noi'i Working Group 2018), was developed through a partnership led by the University of Hawai' i Sea Grant College Program and Kua'āina Ulu 'Auamo (KUA), in consultation with Paepae o He'eia and the He'eia NERR. The Kūlana Noi'i provides guidance for building and sustaining reciprocal collaborations and long-term relationships between researchers and IPLCs. The standards articulated therein are intended to be flexible guidelines adaptable to a range of different communities and to reflect the perspectives and responsibilities of both researchers and communities in the context of equitable and mutually beneficial research partnership. The Külana Noi'i calls for researchers to engage with the community of their study area early and often in the research process. The framework for approaching (both proposing and conducting) research in the He'eia NERR (Fig. 2 ), as modeled by initial research conducted therein (Bremer et al. 2018a, Möhlenkamp et al. 2019, Winter et al. 2020a; Box 1) builds off the Kūlana Noi'i guidance. The framework for reciprocal collaboration used in the He'eia NERR has four main guiding principles: (1) conducting culturally appropriate research; (2) collaboratively developing research; (3) collaboratively producing new knowledge; and (4) informing policy through sharing of collaboratively produced knowledge.

\section{Conducting culturally appropriate research}

Indigenous approaches to resource management provide invaluable insight into sustainable management practices because they document techniques that have been tested and demonstrated as effective over the course of centuries (Ban et al. 2018, Reyes-Garcia et al. 2019). Successful collaborative research projects with Indigenous communities are built on a firm understanding of and respect for reciprocal human-nature relationships. It also operates within the sense of place for those communities, including their genealogical ties to the landscape and biodiversity. In biocultural conservation and restoration efforts, this means conducting research that acknowledges the interconnected relationship between people and nature across both landscapes and seascapes (Poe et al. 2016). This foundation enables an approach that honors the views of that culture regarding life forms, places, and relationships that are sacred, ultimately strengthening and perpetuating these interconnected relationships (Kimmerer 2011, Smith 2013). Humility is required, as is an acceptance that research in academic institutions should be conducted in the context of knowledge accumulated over the course of generations in a single place (Tengö et al. 2017).

He'eia NERR advocates that the key to gaining humility and respect for reciprocal human-nature connection is to foster relationships between people from different worldviews, thereby creating opportunities for exchange of ideas and knowledge between IPLCs and researchers not familiar with the place or the people. We mandate all of our multilevel researchers, from undergraduate interns, graduate research assistants and fellows, to senior university researchers, to first and foremost develop a relationship with $\mathrm{He}^{\text {e }}$ ia as a place by attending community work days and participating in kilo (observation, deep understanding of various natural phenomena; see Fig. 2's collaborative relationship building and issue assessment activity). Through spending physical and spiritual time at the place and with people of the place, researchers can start to frame research questions in a specifically Hawaiian context (e.g., kaulana mahina, the Hawaiian lunar calendar) and begin to think in terms of developing dual fluency of two often contrasting worldviews. Working side by side with IPLCs also helps to break down systemically imposed structures of hierarchy and establish personal relationships of trust.

\section{Collaboratively developing research}

Collaboratively developing research with the IPLC of place will align research questions with community priorities in ways that will cultivate trust, foster relationships, build capacity, and allow community partners to better understand their social-ecological system and pursue their own research questions (Laursen et al. 2018). In fundamental research (often cast as basic versus applied research), it can be challenging to align questions with community priorities. However, as long as the research is not deemed harmful by the community and the researchers follow cultural protocols of giving before taking, then fundamental research can align with the intentions of ensuring that research is beneficial to the socialecological system rather than extractive. In terms of larger, more complex questions (e.g., ecological interactions), efforts must be made to ensure that research contributes positively to community values and priorities. This alignment is built on mutual respect and an understanding of questions that community members have for their own place. It is facilitated by research practices and methods that provide both community members and researchers with decision-making power through each stage of the research process, particularly in refining research questions, goals, and proposal development. In some instances, formal processes including memoranda of understanding between outside researchers and community partners can be useful to clarify expectations, garner collective agreement surrounding collaborative processes, and improve accountability (Minkler 2004). Such an agreement is already in place among the comanagement partners of the He'eia NERR.

Far too often IPLC partners are engaged only after a research project has been designed and funded, and then researchers are surprised to encounter pushback from the community. This is entirely possible even under NOAA's standard, end-user driven approaches to collaborative research (Yaffee and Wondolleck 2010). Only by engaging community partners in all aspects of research, with equal power in decision-making processes, can a project be truly community based. Seeking funding for research projects or otherwise engaging stakeholders from universities, research institutions, and government agencies should take place only after community support is achieved and the community has had the opportunity to shape research questions and objectives (see Fig. 2, Iterative project feedback activity). Researchers, 
Table 2. The priority research topics identified for the inaugural phase of the He'eia National Estuarine Research Reserve via participatory processes that included researchers, collaborative management partners, and IPLC members. Contextual descriptions for each priority research topic is included.

\begin{tabular}{|c|c|}
\hline Priority Research Topic & Contextual Description \\
\hline Historical Ecology & $\begin{array}{l}\text { What and when were the major ecological regime shifts in Hawai } \mathrm{i} \text {, how did these shifts affect ecosystem } \\
\text { services, and how can historical ecology inform restoration and management of contemporary Hawaiian } \\
\text { social-ecological systems? }\end{array}$ \\
\hline Habitat Health & $\begin{array}{l}\text { What are the spatial and temporal variability of physical and biogeochemical processes at the foundation of } \\
\text { healthy watersheds, including a thriving wetland, productive Hawaiian aquaculture systems, and diverse coral } \\
\text { reef ecosystems? How does restoration and maintenance of agroforestry, wetland agro-ecology, and novel } \\
\text { forest types affect water quality, erosion control, nutrient cycling, carbon sequestration, and other ecosystem } \\
\text { services? }\end{array}$ \\
\hline Biological Indicators & $\begin{array}{l}\text { What are the effects of Indigenous resource management on native species richness and abundance within } \\
\text { local-scale habitats in the context of Hawaiian social-ecological systems? }\end{array}$ \\
\hline Restoration of native species & $\begin{array}{l}\text { How does the removal of terrestrial and/or marine invasive species affect ecosystem services and other } \\
\text { indicators of healthy Hawaiian social-ecological systems, such as the presence of native biodiversity? }\end{array}$ \\
\hline Well Being and Human Health & $\begin{array}{l}\text { What are the sociocultural, educational, and economic aspects of ecosystem services, including biocultural } \\
\text { indicators of human health and wellness at collective human scales (e.g., families and communities)? How } \\
\text { does restoration of Hawaiian social-ecological systems help to control microbial contaminants detrimental to } \\
\text { human and animal health? }\end{array}$ \\
\hline Economics & $\begin{array}{l}\text { How can Indigenous resource management be adapted to contribute to robust and resilient community- } \\
\text { based, circular economies in a modern context? }\end{array}$ \\
\hline Climate Change & $\begin{array}{l}\text { What are the effects of changing climate conditions (e.g., intensified storm events, sea-level rise, } \\
\text { eutrophication, ocean acidification) on healthy habitat functioning and ecosystem services? How does } \\
\text { restoration of Hawaiian social-ecological systems promote resilience? }\end{array}$ \\
\hline Scalability of Indigenous Resource & How can Indigenous resource management and the restoration of Hawaiian social-ecological systems in \\
\hline Management & He'eia address issues of conservation and sustainability in Hawai' $\mathrm{i}$ and in other systems? \\
\hline
\end{tabular}

working in places or with resources (e.g., freshwater) that are stewarded by IPLCs, are far more likely to succeed if they follow such an approach. Within He'eia NERR, collaborative management partners are working together to develop sitespecific research protocols that include: (1) an establishment of relationship and respect with place (e.g., through individual relationships or through community work days); (2) transparent communication between researchers and IPLC members regarding specific details of the proposed research (e.g., duration, infrastructure, resources needed, etc.) with understanding that the methodologies will change iteratively through discussion; (3) relatability of research that benefits IPLC organizational goals and mission; and (4) inclusion of IPLCs in formal agreements to determine how data and knowledge generated from research in the places they steward is used (Kūlana Noi'i Working Group 2018).

Research in Kāne'ohe Bay, prior to the establishment of the He'eia NERR, serves as an important example of belated or nonexistent engagement of IPLCs in research. Much of the research historically conducted in the area has been held within the scientific community and lacks a direct relationship to the questions that IPLC members have for their own place. This has led to strained relations between the IPLC and researchers, and a growing sense of negativity toward institutional science. The He'eia NERR endeavors to realign scientific research with community interests and support mutually beneficial communityresearcher partnerships identified through a participatory process with comanagement partners of the He'eia NERR (see Fig. 2, Issue assessment activity). This ongoing iterative process has thus far involved public meetings and focus-group conversations facilitated by the He'eia NERR Coastal Training Program (CTP), which seeks to contextualize research, recognize the value of expertise and knowledge systems not rooted in academic systems, and to guide the use of site-specific research protocols. In addition, the reserve's CTP and education programs have conducted their own data collection, consisting of individual and group interviews, to inform needs assessments and market analyses that will guide the reserve's training and education programs. The themes identified through these reports further inform the reserve's current understanding of the IPLCs research priorities. We have categorized the emergent research questions under the context of ecosystem services gained or recovered through restoration via contemporary and Hawaiian IRM strategies (Table 2).

We acknowledge that although these questions are important during the inaugural phase of the He'eia NERR, we intend to evaluate the focus of these questions frequently in consultation with the comanagement partners as initial research results become available, and as restoration and maintenance efforts evolve (see Fig. 2, Collaborative validation of results activity). Site-specific guidelines outlining the process of obtaining permission and opening dialog between researchers and IPLC members are being developed and adapted in the He'eia NERR. Researchers interested in engaging in collaborative research are encouraged to establish relationships with IPLC members and with the place, then work with IPLC to collaboratively design projects that align with the reserve's priority topics (Table 2; Fig. 2).

\section{Collaboratively producing new knowledge}

The outputs of projects that have been collaboratively developed between researchers and IPLCs constitute new knowledge that can be incorporated in both conventional and Indigenous knowledge systems. Just as the research itself was collaboratively 
designed, the new knowledge coming out of it should be collaboratively produced via a process that includes collaborative validation, not only to check for accuracy, but also to confirm that Indigenous intellectual property is protected and that the information can be shared with broader audiences (see Collaborative validation of results and Information visualization activities in Fig. 2). Workshops (conducted by the He'eia NERR CTP) provide opportunities for communication between IPLCs and researchers throughout the research project, to promote iterative feedback on research methods, practices, and applicability to management strategies (see Fig. 2, Connecting outputs to management and policy activity). Products should be developed to share results in a way that aligns with the communication preferences of the collaborating IPLC members, such that the community, as a whole, will not only have access to, but will also understand and use the information (cf. as described in Pascua et al. 2017, Bremer et al. 2018b; see Fig. 2, IPLC-led outputs product). Inclusion of community collaborators in project outputs and dissemination processes creates an opportunity for IPLC members to contribute their unique knowledge and expertise to interpret results and shape conclusions, which contributes to higher quality research products.

Research outputs should increase access of the local communities to information in a broad sense (See Fig. 2, Increasing access and Education and Outreach activities). To increase access in the short term, He'eia NERR's education program develops curriculum based on current research, specifically targeting local students and educators. To increase community access to information, and the means to produce it, in the long term, the reserve builds the capacity of the next generation of local researchers through college-level classes and internships that facilitate student-driven research. Student-driven research has thus far helped to answer practical management questions and drive development of the reserve's long-term monitoring program (Buskey et al. 2015). By closely intersecting research efforts with education goals, He'eia NERR increases IPLC access to the physical location and research products while creating career pathways for local youth.

An aspiration of the He'eia NERR vision is that the results of the various research projects conducted in the reserve will be communicated in a form that protects Indigenous intellectual property and that honors the intellectual contributions of community collaborators, such as Indigenous people, cultural practitioners, and local elders (kūpuna) of the area. This can be done by inclusion of IPLC on research products with their prior informed consent, advocating for fair, equitable, and inclusive policy regarding authorship and acknowledgements to honor all individuals who contribute to the collaborative design and collaborative production of new knowledge. Potential models include the authorship guidelines developed by the Diversity of the IndoPacific Research Coordination Network (DIPnet) and the Equity in Author Order Protocol (Liboiron et al. 2017), from which He'eia NERR is in the process of developing its own authorship guidelines in collaboration with collaborative management partners.

Just as there are important scientific guidelines for data collection and dissemination, so too are there important ethical guidelines and best practices for information sharing, especially when reporting results outside of the community. When working with IPLCs there must also be special attention paid to locally or culturally sensitive information with regard to the people and places that are potentially impacted. One of the roles of IPLC collaborators is to determine what and how findings are reported outside of the community. For example, community members reasonably object to the public sharing of sensitive information such as the exact GPS coordinates of favored fishing spots or information on the abundance and availability (i.e., biomass) of culturally valued species being shared publicly. However, they could be more amenable to describing a general geographic region or aggregated ecological data for scientific publication. Once feedback and sharing permissions are received, the results reported to broader audiences should be done in a manner that honors the data sharing wishes and intellectual contributions of all those involved in the research.

\section{Informing policy through sharing of collaboratively produced knowledge}

As we find ourselves at the dawn of the Anthropocene and a 6th global mass extinction (Lewis and Maslin 2015), societies urgently seek solutions that address climate change in the context of habitat degradation and loss, as well as the overextraction of natural resources, while supporting larger populations (Mora et al. 2018, IPCC 2019). It is imperative to engage ILK in this process (Grossman 2008, Nakashima et al. 2012, Burkett 2013). Prioritizing applied research to focus limited time, energy, and resources on identifying positive and negative drivers of ecosystem services will inform adaptive comanagement in sitespecific contexts. The He'eia community, however, also maintains connections to a broader web of organizations and partners leading place-based efforts to restore Hawaiian social-ecological systems across the archipelago. The collective impact of these efforts contributes to policy (e.g., laws, rules, and regulations, government initiatives, and/or strategic plans) at all levels of government. By sharing and analyzing applied, place-based research across these networks, we hope to inform policy, specifically in the realms of conservation and sustainability, to address larger-scale problems and structural issues inhibiting restoration of social-ecological systems. Ideally, such research syntheses should highlight sustainability solutions in a global context (Díaz et al. 2019). Doing so is especially important with regard to aligning efforts to improve local-level well-being with international policy, such as the UN Sustainable Development Goals (Sterling et al. 2020). Although we recognize the value of fundamental discipline-specific research (i.e., basic, conceptual, or theoretical explorations), the He'eia NERR advocates for interdisciplinary, policy-oriented applied research that views humans as part of the ecosystem. He'eia NERR facilitates collaborative development of such research through CTP workshops that facilitate knowledge exchange among researchers, IPLC members, stakeholders, resource managers, and decision makers.

The He'eia NERR provides one such model for conducting and otherwise supporting policy-oriented research, informed by IRM and ILK, to guide the adaptive comanagement within $\mathrm{He}^{\text {'eia }}$ and inform related efforts in other communities. As we continue to more deeply understand the regional variations in the original design, structure, and function of Hawaiian social-ecological 
systems, we can better gauge which approaches can be resurrected and adapted on larger scales in the 21 st century. The data provided from various case studies throughout Hawai i, like those from Mo'omomi on the Island of Moloka'i (Friedlander et al. 2002, Poepoe et al. 2003), and from both Hā'ena on the Island of Kaua' $i$ and Ka'ūpūlehu on Hawai'i Island (Winter and Lucas 2017, Burnett et al. 2018, Delevaux et al. 2018, 2019, Winter et al. 2020b), as well as initial studies conducted within the He'eia NERR (e.g., Bremer et al. 2018a, Möhlenkamp et al. 2019), can inform policy and adaptive comanagement throughout Hawai'i. These case studies, in conjunction with contributions that represent a broader synthesis of such thinking (Matsuoka et al. 1998, McGregor et al. 2003, Winter et al. 2020a), can illuminate how Hawaiian socialecological systems can be a model for managing human-in-nature systems, particularly in terms of EBM, as well as for human wellbeing (Price and Toonen 2017, Gon and Winter 2019).

Box 1: Following guidelines for reciprocal collaboration in research: a case study in research that informs policy regarding sustainable development in Hawai' $i$

\section{Conducting culturally appropriate research}

Since 2013, Rosie Alegado has partnered with Paepae o He'eia $(\mathrm{POH})$ to understand the microbial ecology of He'eia Fishpond. As part of building strong relationships to the people and place, all members of her group participate in community work days and have contributed to educational programming at He'eia Fishpond. Because of this established relationship of trust $\mathrm{POH}$ asked Alegado to serve as an informal research coordinator for He'eia Fishpond in 2016. Her lab collaboratively designed their sampling regime to be consistent with practitioner monitoring sites and to align with the kaulana mahina (moon/tidal phases). Alegado's research hypotheses are based on Indigenous knowledge drawn from Hawaiian language primary sources and kūpuna (elders) of the area. Alegado also partners with $\mathrm{POH}$ to host biannual Fishpond Science Nights that bring together IPLCs and members of the University community to share food and exchange knowledge.

\section{Collaboratively developing research}

To support their biocultural restoration efforts in an Indigenous aquaculture system (including the removal of invasive mangrove trees), $\mathrm{POH}$ and the University of Hawai'i Sea Grant College Program identified a funding opportunity that required water quality monitoring as part of their restoration plan. Paepae o He'eia reached out to long-time research partner, Alegado, for assistance. The result was an applied research project that met a grant deliverable narrowly, while informing POH's restoration strategy broadly. A research question was collaboratively developed around understanding and characterizing the environmental changes that resulted from the massive restoration efforts. Sampling sites were chosen together by researchers and IPLC practitioners who possessed relevant ILK, and timing and frequency of sampling was adjusted in consultation with the IPLC members leading the project. Paepae o He'eia staff were full participants in data collection and analysis alongside Alegado lab members.

\section{Collaboratively producing new knowledge}

Novel biological proxies to human health indicators regarding water quality were identified, through a collaborative process, to ensure protection of sensitive data. Subsequently Alegado's group produced new molecular markers for these novel proxy indicators. Once completed, the research was published with the IPLC members, who contributed their intellectual property in the design process, as coauthors (e.g., Möhlenkamp et al. 2019). Research results were also presented to the public at He'eia Fishpond Science Nights.

4. Informing policy in the realms of conservation and sustainability

As a result of this study, government agencies have a better understanding of the connection between removal of invasive mangrove and improvements to water quality. This restoration project is now held up as a model for sustainable development in policy circles, especially those around the state-sanctioned Hawai'i Green Growth initiative and the Sustainable Hawai' $i$ goals.

Fig. 3. An aerial view of He'eia Fishpond, the largest

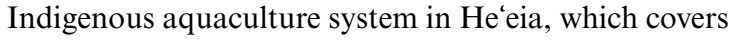
approximately 36 hectares ( 88 acres) of the estuary and is stewarded by Paepae o He'eia (a comanagement partner in the He'eia NERR). It is estimated to be approximately 800 years old, and, after falling into disrepair and being inundated with invasive mangroves for several decades, has been the focus of biocultural restoration efforts since 2001. Photo credit: Keli ‘ $i$ Kotubetey.

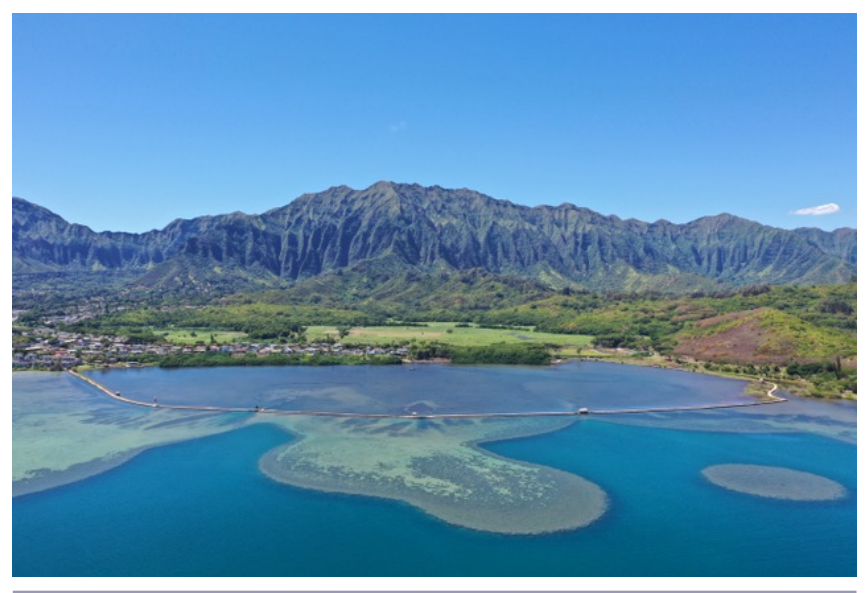

\section{CONCLUSIONS}

Indigenous people and local communities seek to decolonize the systems that influence their lives and to aspire to implement creative, place-based solutions to restore self-sufficiency at the community level. The He'eia NERR represents a step toward achieving that vision, in part, by facilitating adaptive comanagement within an ICCA, and by having IPLCs play a 
leading role in identifying problems, collaboratively developing research, collaboratively producing new knowledge, and influencing policy. This program joins many others in different regions around the world as the vanguard of efforts to change the way research is conducted and shift paradigms that drive how communities operate and thrive in a larger context. It supports the growing recognition that conventional science should not be extractive of IPLCs, but can engage in reciprocal collaboration with Indigenous science and other forms of ILK in support of the global movement toward more sustainable and resilient communities.

This concept paper establishes a framework for engaging in collaborative management within an ICCA and guidance for conducting collaborative research with IPLCs. The latter, in particular, is embodied by a fundamental question, a list of our initial phase of research priorities, and guiding principles and protocols emphasizing reciprocal collaboration, iterative engagement, and increasing access. The results of such research will inform adaptive comanagement between IPLCs and government agencies that incorporate new knowledge by weaving Indigenous and conventional knowledge systems. This can further be used to fill knowledge gaps and influence policy initiatives in Hawai' $i$ such as the Sustainable Hawai' i initiative and the Hawai'i Green Growth initiative. This research can also help the University of Hawai'i at Mānoa to fulfill its expressed commitment of being a foremost Indigenous-serving institution and of advancing sustainability.

As Hawai'i, and He'eia specifically, revitalizes and adapts ancestral engineering and Indigenous approaches to adaptively managing social-ecological systems, the lessons learned here can be exported on a global scale. This model addresses global issues including habitat restoration, endangered species recovery, and sustainable food systems, all of which supports cultural revitalization and broader conceptualizations of resilience in the 21 st century. In this regard, the He'eia NERR is uniquely positioned to contribute to the ongoing debate about best practices for EBM within the paradigm of social-ecological systems.

Responses to this article can be read online at: http://www.ecologyandsociety.org/issues/responses. $\mathrm{php} / 11895$

\section{Acknowledgments:}

This research was conducted in part under an award from the Office for Coastal Management, National Ocean Service, National Oceanic and Atmospheric Administration (award number NA19NOS4200078). We thank the administration at both the University of Hawaì $i$ at Mānoa and at the Office for Coastal Management within the National Oceanic and Atmospheric Administration for their continued support of the He'eia NERR. We also thank the collaborative management partners of the He'eia National Estaurine Research Reserve (HeNERR) for their commitment of collaboration in establishing and maintaining the research reserve. They are the Hawai i Institute of Marine Biology,
Kāko'o 'Ōiwi, Paepae o He'eia, Ko'olaupoko Hawaiian Civic Club, Ko'olau Foundation, the Hawai $i$ Community Development Authority, and the State of Hawai $i$, Department of Land and Natural Resources. We also express deep appreciation to Eric Enos, Kelson "Mac" Poepoe, Davianna McGregor, 'Aulani Wilhelm, Kamanamaikalani Beamer, Mehana Vaughan, Peter Vitousek, Alan Friedlander, Jade Delevaux, TNC Hawai' i and Eric Conklin, Sea Grant Hawai'i and Darren Lerner, Kua'àina Ulu 'Auamo (KUA), Maxx Phillips, Dawn Chang, Will McClatchey, Fikret Berkes, and the late Jerry Kaluhiwa for inspiring and influencing the ideas that were explored in this paper. We also thank the late Ruth Gates, former Director of HIMB; and, Judy Lemus, the current Interim Director of HIMB; as well as Brian Taylor, the Dean of SOEST, and Michael S. Bruno, Provost for the University of Hawaì $i$ at Mānoa, for supporting the He'eia NERR. Finally, this publication honors the centennial celebration of the life of Professor Isabella Kauakea Aiona Abbott, the first Native Hawaiian to receive a Ph.D. in science. This Indigenous woman, native speaker, and cultural practitioner paved the path for Native Hawaiians in science, as well as for women in botany, phycology, and ethnobotany. She saw the importance of marine plants in Hawaiian coastal ecosystems and gave us the tools, via her disciplined and rigorous scholarship, to study mechanistic linkages between land and coastal productivity. Professor Abbott was a teacher and mentor to several of the authors of this concept paper. We endeavor to honor her legacy.

\section{Data Availability:}

There is no relevant data nor code underlying the findings described in this manuscript.

\section{LITERATURE CITED}

Abbott, I. A. 1992. Lāa au Hawaì i: traditional Hawaiian uses of plants. Bishop Museum Press, Honolulu, Hawai i USA.

Adams, W. M., and J. Hutton. 2007. People, parks and poverty: political ecology and biodiversity conservation. Conservation and Society 5(2):147-183. [online] URL: http://www.conservationandsociety. org/text.asp?2007/5/2/147/49228

Akutagawa, M., E. Cole, T. P. Diaz, T. D. Gupta, C. Gupta, A. Fa'anunu, S. Kamaka'ala, and M. Taualii. 2016a. Health impact assessment of the proposed Mo'omomi community-based subsistence fishing area - Island of Moloka i $i$, Hawai $i$. The Kohala Center, Kamuela, Hawai'i, USA. [online] URL: https:// scholarspace.manoa.hawaii.edu/bitstream/10125/46016/ Moomomi HIA FullReport Web Final.pdf

Akutagawa, M., H. Williams, and S. Kamaka'ala. $2016 b$. Traditional and customary practices report for Mana'e, Moloka' $i$ : traditional subsistence uses, mālama practices and recommendations, and native Hawaiian rights protections of kama'āina families of Mana' e moku, east Moloka'i, Hawai i. Office of Hawaiian Affairs, Honolulu, Hawai i, USA. [online] URL: https://scholarspace. manoa.hawaii.edu/handle/10125/46017

Alegado, R. 2019. Opponents of the Thirty Meter Telescope fight the process, not science. Nature 572(7767):7. https://doi. org/10.1038/d41586-019-02304-1 
Andrade, C. 2008. Hā'ena: through the eyes of the ancestors. University of Hawai i Press, Honolulu, USA.

Ayers, A. L., J. N. Kittinger, and M. B. Vaughan. 2018. Whose right to manage? Distribution of property rights affects equity and power dynamics in comanagement. Ecology and Society 23 (2):37. https://doi.org/10.5751/ES-10124-230237

Bahr, K. D., P. L. Jokiel, and R. J. Toonen. 2015. The unnatural history of Kāne ohe Bay: coral reef resilience in the face of centuries of anthropogenic impacts. PeerJ 3:e950. https://doi. org/10.7717/peerj. 950

Ban, N. C., A. Frid, M. Reid, B. Edgar, D. Shaw, and P. Siwallace. 2018. Incorporate Indigenous perspectives for impactful research and effective management. Nature Ecology and Evolution 2 (11):1680-1683. https://doi.org/10.1038/s41559-018-0706-0

Beamer, K. 2014. No Mākou ka Mana: liberating the nation. Kamehameha, Honolulu, Hawai'i, USA.

Bennett, N. J., A. Di Franco, A. Calò, E. Nethery, F. Niccolini, M. Milazzo, and P. Guidetti. 2019. Local support for conservation is associated with perceptions of good governance, social impacts, and ecological effectiveness. Conservation Letters e12640. https:// doi.org/10.1111/conl.12640

Berkes, F. 2009a. Community conserved areas: policy issues in historic and contemporary context. Conservation Letters 2 (1):20-25. https://doi.org/10.1111/j.1755-263x.2008.00040.x

Berkes, F. 2009b. Evolution of co-management: role of knowledge generation, bridging organizations and social learning. Journal of Environmental Management 90:1692-1702. https://doi.org/10.1016/ j.jenvman.2008.12.001

Berkes, F. 2009c. Indigenous ways of knowing and the study of environmental change. Journal of the Royal Society of New Zealand 39(4):151-156. https://doi.org/10.1080/03014220909510568

Berkes, F. 2018. Sacred ecology. Fourth edition. Routledge, New York, New York, USA.

Bremer, L. L., K. Falinski, C. Ching, C. A. Wada, K. M. Burnett, K. Kukea-Shultz, N. Reppun, G. Chun, K. L. L. Oleson, and T. Ticktin. 2018a. Biocultural restoration of traditional agriculture: cultural, environmental, and economic outcomes of lo i kalo restoration in $\mathrm{He}^{\prime}$ eia, O`ahu. Sustainability 10(12):4502. https:// doi.org/10.3390/su10124502

Bremer, L. L., L. Mandle, C. Trauernicht, P. Pascua, H. L. McMillen, K. Burnett, C. A. Wada, N. Kurashima, S. A. Quazi, T. Giambelluca, and P. Chock. 2018b. Bringing multiple values to the table: assessing future land-use and climate change in North Kona, Hawai'i. Ecology and Society 23(1):33. https://doi. org/10.5751/ES-09936-230133

Burkett, M. 2013. Indigenous environmental knowledge and climate change adaptation. Pages 96-118 in R. S. Abate and E. A. Kronk, editors. Climate change and Indigenous peoples: the search for legal remedies. Edward Elgar, London, UK. https://doi. org/10.4337/9781781001806.00014

Burnett, K., T. Ticktin, L. L. Bremer, S. Quazi, C. Geslani, C. Wada, N. Kurashima, L. Mandle, P. Pascua, T. Depraetere, D. Wolkis, M. Edmonds, T. Giambelluca, K. Falinski, and K. B.
Winter. 2018. Restoring to the future: environmental, cultural, and management tradeoffs in historical versus hybrid restoration of a highly modified ecosystem. Conservation Letters 2018: e12606. https://doi.org/10.1111/conl.12606

Buskey, E. J., M. Bundy, M. C. Ferner, D. E. Porter, W. G. Reay, E. Smith, and D. Trueblood, 2015. System-wide monitoring program of the National Estuarine Research Reserve system: research and monitoring to address coastal management issues. Pages 392-415 in Y. Liu, H. Kerkering, and R. H. Weisberg, editors. Coastal ocean observing systems: advances and syntheses. Elsevier, Amsterdam, The Netherlands. https://doi.org/10.1016/ b978-0-12-802022-7.00021-3

Canadian International Development Agency (CIDA). 2002. Handbook of CIDA project planning and Indigenous traditional knowledge. Canadian International Development Agency, Ottawa, Ontario, Canada. [online] URL: https://kivu.com/wpcontent/uploads/2012/01/CIDA-Guidelines.pdf

Carlsson, L., and F. Berkes. 2005. Co-management: concepts and methodological implications. Journal of Environmental Management 75(1):65-76. https://doi.org/10.1016/j.jenvman.2004.11.008

Chan, K. M. A., P. Balvanera, K. Benessaiah, M. Chapman, S. Díaz, E. Gómez-Baggethun, R. Gould, N. Hannahs, K. Jax, S. Klain, G. W. Luck, B. Martín-López, B. Muraca, B. Norton, K. Ott, U. Pascual, T. Satterfield, M. Tadaki, J. Taggart, and N. Turner. 2016. Opinion: why protect nature? Rethinking values and the environment. Proceedings of the National Academy of Sciences 113(6):1462-1465. https://doi.org/10.1073/pnas.1525002113

Chang, K., K. B. Winter, and N. K. Lincoln. 2019a. Hawai' i in focus: navigating pathways in global biocultural leadership. Sustainability 11(1):283. https://doi.org/10.3390/su11010283

Chang, K., C. Young, B. Asuncion, W. Ito, and K. B. Winter. 2019b. Kua āina Ulu 'Auamo: grassroots growing through shared responsibility. Pages 122-154 in D. A. Mihesuah and E. Hoover, editors. Indigenous food sovereignty: restoring cultural knowledge, protecting environments, and regaining health. University of Oklahoma Press, Norman, Oklahoma, USA.

Chinn, P. W. U., S. Businger, K. Lance, J. K. Ellinwood, J. K. Stone, L. Spencer, F. W. McCoy, M. P. Nogelmeier, and S. K. Rowland. 2014. Kahua A 'o - a learning foundation: using Hawaiian language newspaper articles for earth science professional development. Journal of Geoscience Education 62 (2):217-226. https://doi.org/10.5408/13-019.1

Climate and Traditional Knowledges Workgroup (CTKW). 2014. Guidelines for considering traditional knowledges in climate change initiatives. Climate and Traditional Knowledges Workgroup. [online] URL: https://climatetkw.wordpress.com

Comberti, C., T. F. Thornton, V. Wyllie de Echeverria, and T. Patterson. 2015. Ecosystem services or services to ecosystems? Valuing cultivation and reciprocal relationships between humans and ecosystems. Global Environmental Change 34(September):247-262. https://doi.org/10.1016/j.gloenvcha.2015.07.007

Coombes, B. L., and S. Hill. 2005. "Na whenua, na Tuhoe. Ko DoC te partner" - Prospects for comanagement of Te Urewera National Park. Society and Natural Resources 18(2):135-152. https://doi.org/10.1080/08941920590894516 
Costa-Pierce, B. A. 2008. Ecological aquaculture: the evolution of the blue revolution. John Wiley and Sons, Hoboken, New Jersey, USA. https://doi.org/10.1002/9780470995051

Crutzen, P. J. 2006. The "anthropocene.” Pages 13-18 in E. Ehlers and T. Krafft, editors. Earth system science in the anthropocene. Springer, Berlin, Germany. https://doi.org/10.1007/3-540-26590-2 3

David-Chavez, D. M., and M. C. Gavin. 2018. A global assessment of Indigenous community engagement in climate research. Environmental Research Letters 13(12):123005. https:// doi.org/10.1088/1748-9326/aaf300

Díaz, S., J. Settele, E. Brondízio, H. T. Ngo, M. Guèze, J. Agard, A. Arneth, P. Balvanera, K. Brauman, S. Butchart, K. Chan, L. Garibaldi, K. Ichii, J. Liu, S. M. Subramanian, G. Midgley, P. Miloslavich, Z. Molnár, D. Obura, A. Pfaff, S. Polasky, A. Purvis, J. Razzaque, B. Reyers, R. R. Chowdhury, Y.-J. Shin, I. VisserenHamakers, K. Willis, and C. Zayas. 2019. The global assessment report on biodiversity and ecosystem services: summary for policymakers. IPBES Secretariat, Bonn, Germany. https://doi. org/10.5281/zenodo.3553579

Delevaux, J. M. S., K. A. Stamoulis, R. Whittier, S. D. Jupiter, L. L. Bremer, A. Friedlander, N. Kurashima, J. Giddens, K. B. Winter, M. Blaich-Vaughan, K. M. Burnett, C. Geslani, and T. Ticktin. 2019. Place-based management can reduce human impacts on coral reefs in a changing climate. Ecological Applications 29(4):e01891. https://doi.org/10.1002/eap.1891

Delevaux, J. M. S., K. B. Winter, S. D. Jupiter, M. Blaich-Vaughan, K. A. Stamoulis, L. L Bremer, K. Burnett, P. Garrod, J. L. Troller, and T. Ticktin. 2018. Linking land and sea through collaborative research to inform contemporary applications of traditional resource management in Hawai'i. Sustainability 10:3147. https:// doi.org/10.3390/su10093147

Denevan, W. M. 1992. The pristine myth: the landscape of the Americas in 1492. Annals of the Association of American Geographers 82(3):369-385. https://doi.org/10.1111/j.1467-8306.1992. tb01965.x

Domínguez, L., and C. Luoma. 2020. Decolonising conservation policy: how colonial land and conservation ideologies persist and perpetuate Indigenous injustices at the expense of the environment. Land 9(3):65. https://doi.org/10.3390/land9030065

Dye, T., and E. Komori. 1992. A pre-censal population history of Hawai' i. New Zealand Journal of Archaeology 14:113-128. [online] URL: https://nzarchaeology.org/download/pre-censal-populationhistory-of-hawaii

Eckert, L., N. Ban, S.-C. Tallio, and N. Turner. 2018. Linking marine conservation and Indigenous cultural revitalization: First Nations free themselves from externally imposed socialecological traps. Ecology and Society 23(4):23. https://doi. org/10.5751/ES-10417-230423

Ellis, W. 2004. Journal of William Ellis - A narrative of a tour through Hawai $i$ in 1823. Mutual, Honolulu, Hawai' $i$, USA.

Escobar, A. 1998. Whose knowledge, whose nature? Biodiversity, conservation, and the political ecology of social movements. Journal of Political Ecology 5(1):53-82. https://doi.org/10.2458/ v5i1.21397
Fisher, P. A., and T. J. Ball. 2003. Tribal participatory research: mechanisms of a collaborative model. American Journal of Community Psychology 32(3-4):207-216. https://doi.org/10.1023/ B:AJCP.0000004742.39858.c5

Fisher, S. 2015. Hawaiian culture and its foundation in sustainability. Pages 7-27 in J. Chirico and G. S. Farley, editors. Thinking like an island: navigating a sustainable future in Hawai $i$. University of Hawai'i Press, Honolulu, Hawai'i, USA. https://doi. org/10.21313/hawaii/9780824847616.003.0002

Friedlander, A., K. Poepoe, K. Poepoe, K. Helm, P. Bartram, J. Maragos, and I. Abbott. 2002. Application of Hawaiian traditions to community-based fishery management. Pages 813-818 in M. K. Moosa and S. Soemodihardio, editors Proceedings of the Ninth International Coral Reef Symposium, Bali, 23-27 October 2000. Ministry of Environment, Jakarta, Indonesia. http://coremap.or.id/downloads/ICRS9th-Friedlander. pdf

Garnett, S. T., N. D. Burgess, J. E. Fa, Á. Fernández-Llamazares, Z. Molnár, C. J. Robinson, J. E. M. Watson, K. K. Zander, B. Austin, E. S. Brondízio, N. French Collier, T. Duncan, E. Ellis, H. Geyle, M. V. Jackson, H. Jonas, P. Malmer, B. McGowan, A. Sivongxay, and I. Leiper 2018. A spatial overview of the global importance of Indigenous lands for conservation. Nature Sustainability 1(7):369-374. https://doi.org/10.1038/s41893-018-0100-6

Gavin, M. C., J. McCarter, F. Berkes, A. T. P. Mead, E. J. Sterling, R. Tang, and N. Turner. 2018. Effective biodiversity conservation requires dynamic, pluralistic, partnership-based approaches. Sustainability 10(6):1846. https://doi.org/10.3390/su10061846

Gon, S. M., III, and K. B. Winter. 2019. A Hawaiian renaissance that could save the world. American Scientist 107:232-239. https:// doi.org/10.1511/2019.107.4.232

Goodyear-Ka'opua, N., I. Hussey, and E. K. A. Wright. 2014. A nation rising: Hawaiian movements for life, land, and sovereignty. Duke University Press, Durham, North Carolina, USA. https:// doi.org/10.1215/9780822376552

Gorenflo, L. J., S. Romaine, R. A. Mittermeier, and K. WalkerPainemilla. 2012. Co-occurrence of linguistic and biological diversity in biodiversity hotspots and high biodiversity wilderness areas. Proceedings of the National Academy of Sciences 109 (21):8032-8037. https://doi.org/10.1073/pnas.1117511109

Gould, R. K., M. Pai, B. Muraca, and K. M. A. Chan. 2019. He 'ike 'ana ia i ka pono (it is a recognizing of the right thing): how one Indigenous worldview informs relational values and social values. Sustainability Science 14(5):1213-1232. https://doi. org/10.1007/s11625-019-00721-9

Grossman, Z. 2008. Indigenous Nations' responses to climate change. American Indian Culture and Research Journal 32(3):5-27. [online] URL: https://sites.evergreen.edu/zoltan/wp-content/ uploads/sites/358/2019/09/Indigenous-Nations-Responses.pdf https:// doi.org/10.17953/aicr.32.3.n561082k204u153g

Guha, R. 1989. Radical American environmentalism and wilderness preservation: a third world critique. Environmental Ethics 11:71-83. [online] URL: https://www.uky.edu/ rsand1/ china2017/library/Guha.pdf 
Handy, E. S. C., E. G. Handy, and M. K. Pukui. 1972. Native planters in old Hawai $i$ : their life, lore, and environment. Bishop Museum, Honolulu, Hawai'i, USA.

Hawai'i Office of Planning. 2016. Héeia National Estuarine Research Reserve management plan 2016-2021. National Oceanic and Atmospheric Administration. Honolulu, Hawai i, USA. [online] URL: https://coast.noaa.gov/data/docs/nerrs/hawaiireserve-final-mgmt-plan.pdf

Howitt, R. 2018. Indigenous rights vital to survival. Nature Sustainability 1(7):339-340. https://doi.org/10.1038/s41893-018-0105-1

Hunt, T., and C. Lipo. 2011. The statues that walked: unraveling the mystery of Easter Island. Simon and Schuster, New York, New York, USA.

Intergovernmental Panel on Climate Change (IPCC). 2018. Summary for policymakers. In V. Masson-Delmotte, P. Zhai, H.O. Pörtner, D. Roberts, J. Skea, P. R. Shukla, A. Pirani, W. Moufouma-Okia, C. Péan, R. Pidcock, S. Connors, J. B. R. Matthews, Y. Chen, X. Zhou, M. I. Gomis, E. Lonnoy, T. Maycock, M. Tignor, and T. Waterfield, editors. Global warming of $1.5^{\circ} \mathrm{C}$. Intergovernmental Panel on Climate Change, Geneva, Switzerland. [online] URL: https://www.ipcc.ch/site/assets/ uploads/sites/2/2019/05/SR15 SPM version report LR.pdf

Intergovernmental Panel on Climate Change (IPCC). 2019. Climate change and land: an IPCC special report on climate change, desertification, land degradation, sustainable land management, food security, and greenhouse gas fluxes in terrestrial ecosystems. Intergovernmental Panel on Climate Change, Geneva, Switzerland. [online] URL: https://www.ipcc.ch/srccl/

International Society of Ethnobiology (ISE). 2006. International Society of Ethnobiology code of ethics (with 2008 additions). International Society of Ethnobiology, Gainesville, Florida, USA. [online] URL: http://ethnobiology.net/code-of-ethics/

International Union for the Conservation of Nature (IUCN). 2016. Navigating island Earth: the Hawai $i$ commitments. International Union for the Conservation of Nature, Gland, Switzerland. [online] URL: https://www.iucn.org/sites/dev/files/ en navigating island earth - hawaii commitments final.pdf

Johannes, R. E. 1978. Traditional marine conservation methods in Oceania and their demise. Annual Review of Ecology and Systematics 9(1):349-364. https://doi.org/10.1146/annurev. es.09.110178.002025

Johnson, F. D. 2008. Fostering the development of reciprocal collaboration between mainstream teachers and collaborating teachers. Dissertation. Rowan University, Glassboro, New Jersey, USA.

Jokiel, P. L., K. S. Rodgers, W. J. Walsh, D. A. Polhemus, and T. A. Wilhelm. 2011. The traditional Hawaiian system in relation to the western approach of coral reef resource management. Journal of Marine Biology 2011:151682. https://doi.org/10.1155/2011/151682

Kamakau, S. M. 1976. Ka Hana a ka Po'e Kahiko: the works of the people of old. Bishop Museum Press, Honolulu, Hawai'i, USA.

Kashwan, P. 2020. American environmentalism's racist roots have shaped global thinking about conservation. The Conversation, 2
September. [online] URL: https://theconversation.com/americanenvironmentalisms-racist-roots-have-shaped-global-thinking-aboutconservation-143783

Kikuchi, W. K. 1976. Prehistoric Hawaiian fishponds. Science 193:295-299. https://doi.org/10.1126/science.193.4250.295

Kimmerer, R. 2011. Restoration and reciprocity: the contributions of traditional ecological knowledge. Pages 257-276 in D. Egan, E. E. Hjerpe, and J. Abrams, editors. Human dimensions of ecological restoration. Island, Washington, D.C., USA. https://doi.org/10.5822/978-1-61091-039-2 18

Kirkness, V. J., and R. Barnhardt. 2001. First Nations and higher education: the four r's - respect, relevance, reciprocity, responsibility. In R. Hayoe and J. Pan, editors. Knowledge across cultures: a contribution to dialogue among civilizations. Comparative Education Research Centre, University of Hong Kong, Pok Fu Lam, Hong Kong. [online] URL: https://uaf.edu/ ankn/publications/collective-works-of-ray-b/Four-Rs-2nd-Ed.pdf

Kittinger, J. N., J. M. Pandolfi, J. H. Blodgett, T. L. Hunt, H. Jiang, K. Maly, L. E. McClenachan, J. K. Schultz, and B. A. Wilcox. 2011. Historical reconstruction reveals recovery in Hawaiian coral reefs. PLoS One 6(10):e25460. https://doi. org/10.1371/journal.pone.0025460

Kubota, G. T. 2018. Hawai i stories of change: an oral history project. ISBN 978-0-9799467-2-1. Hawai'i Council for the Humanities and the Hawai'i People's Fund, Hawai'i. [online] URL: https://scholarspace.manoa.hawaii.edu/bitstream/10125/59404/1/ KHOHP.pdf

Kūlana Noi'i Working Group. 2018. Kūlana Noì $i$ v. 1. Hawai'i Sea Grant, Honolulu, Hawai'i, USA. [online] URL: http:// seagrant.soest.hawaii.edu/wp-content/uploads/2018/06/Kulana-Noiilow-res-web.pdf

Kurashima, N., L. Fortini, and T. Ticktin. 2019. The potential of indigenous agricultural food production under climate change in Hawai i. Nature Sustainability 2:191-199. https://doi.org/10.1038/ s41893-019-0226-1

Kurashima, N., J. Jeremiah, A. N. Whitehead, J. Tulchin, M. Browning, and T. Duarte. 2018. 'āina Kaumaha: the maintenance of ancestral principles for 21 st century Indigenous resource management. Sustainability 10(11):3975. https://doi.org/10.3390/ $\underline{\text { su10113975 }}$

Laurance, W. F., D. C. Useche, J. Rendeiro, M. Kalka, C. J. A. Bradshaw, S. P. Sloan, S. G. Laurance, M. Campbell, K. Abernethy, P. Alvarez et al. 2012. Averting biodiversity collapse in tropical forest protected areas. Nature 489(7415):290-294. https://doi.org/10.1038/nature11318

Laursen, S., N. Puniwai, A. S. Genz, S. A. B. Nash, L. K. Canale, and S. Ziegler-Chong. 2018. Collaboration across worldviews: managers and scientists on Hawai i Island utilize knowledge coproduction to facilitate climate change adaptation. Environmental Management 62(4):619-630. https://doi.org/10.1007/ s00267-018-1069-7

Levin, P. S., and C. Möllmann. 2015. Marine ecosystem regime shifts: challenges and opportunities for ecosystem-based management. Philosophical Transactions of the Royal Society of 
London B: Biological Sciences 370(1659):20130275. https://doi. org/10.1098/rstb.2013.0275

Lewis, S. L., and M. A. Maslin. 2015. Defining the Anthropocene. Nature 519:171-180 https://doi.org/10.1038/nature14258

Liboiron, M., J. Ammendolia, K. Winsor, A. Zahara, H. Bradshaw, J. Melvin, C. Mather, N. Dawe, E. Wells, F. Liboiron, B. Fürst, C. Coyle, J. Saturno, M. Novacefski, S. Westscott, and Grandmother Liboiron. 2017. Equity in author order: a feminist laboratory's approach. Catalyst: Feminism, Theory, Technoscience 3(2):1-17. https://doi.org/10.28968/cftt.v3i2.28850

Lincoln, N. K., J. Rossen, P. Vitousek, J. Kahoonei, D. Shapiro, K. Kalawe, M. Pai, K. Marshall, and K. Meheula. 2018. Restoration of 'aina malo'o on Hawai'i Island: expanding biocultural relationships. Sustainability 10(11):3985. https://doi. org/10.3390/su10113985

Loke, M. K., and P. Leung. 2013. Hawai'i's food consumption and supply sources: benchmark estimates and measurement issues. Agricultural Food and Economics 1:10. https://doi. org/10.1186/2193-7532-1-10

Maffi, L. 2005. Linguistic, cultural, and biological diversity. Annual Review of Anthropology 34(1):599-617. https://doi. org/10.1146/annurev.anthro.34.081804.120437

Maly, K., and O. Maly. 2003. Ka Hana Lawai'a a me nā Ko' a o nā Kai 'Ewalu: summary of detailed findings from research on the history of fishing practices and marine fisheries on the Hawaiian Islands. A Kumu Pono Associates report for The Nature Conservancy of Hawai i. The Nature Conservancy of Hawai'i, Honolulu, Hawai', USA. [online] URL: http://www.ulukau.org/ elib/cgi-bin/library?c $=$ maly $3 \& \mathrm{l}=$ en

Matsuoka, J. K., D. P. McGregor, and L. Minerbi. 1998. Molokai: a study of Hawaiian subsistence and community sustainability. Pages 25-44 in M. D. Hoff, editor. Sustainable community development: studies in economic, environmental, and cultural revitalizations. CRC Press, Boca Raton, Florida, USA.

McGregor, D. P. I., P. Morelli, J. Matsuoka, L. Minerbi, H. A. Becker, and F. Vanclay. 2003. An ecological model of well-being. Pages 109-126 in H. A. Becker and F. Vanclay, editors. The international handbook of social impact assessment: conceptual and methodological advances. Edward Elgar, London, UK.

McGregor-Alegado, D. 1980. Hawaiians: organizing in the 1970s. Amerasia Journal 7(2):29-55. https://doi.org/10.17953/amer.7.2. $\underline{\mathrm{d} 331761876682740}$

McLeod, K., and H. Leslie. 2009. Ecosystem-based management for the oceans. Island, Washington, D.C., USA.

Minerbi, L. 1999. Indigenous management models and protection of the Ahupua'a. Social Process in Hawaiti 39:208-225. [online] URL: http://www2.hawaii.edu/ aoude/ES350/SPIH vol39/16Minerbi. pdf

Minerbi, L. 2001. In the face of globalization: two decades of insurgent localism in Hawai'i. Social Process in Hawai $i$ 40:165-189. [online] URL: http://www2.hawaii.edu/ aoude/ ES350/SPIH vol40/09MinerbiSocProc40 2001 pp.165-89.pdf
Minkler, M. 2004. Ethical challenges for the "outside" researcher in community-based participatory research. Health Education and Behavior 31(6):684-697. https://doi.org/10.1177/1090198104269566

Möhlenkamp, P., C. K. Beebe, M. A. McManus, A. H. Kawelo, K. Kotubetey, M. Lopez-Guzman, C. E. Nelson, and R. A. Alegado. 2019. Kū Hou Kuapā: cultural restoration improves water budget and water quality dynamics in He'eia fishpond. Sustainability 11(1):161. https://doi.org/10.3390/su11010161

Mora, C., D. Spirandelli, E. C. Franklin, J. Lynham, M. B. Kantar, W. Miles, C. Z. Smith, K. Freel, J. Moy, L. V. Louis, E. W. Barba, K. Bettinger, A. G. Frazier, J. F. Colburn, IX, N. Hanasaki, E. Hawkins, Y. Hirabayashi, W. Knorr, C. M. Little, K. Emanuel, J. Sheffield, J. A. Patz, and C. L. Hunter. 2018. The broad risk to humanity from climate change. Nature Climate Change 8:1062-1071 https://doi.org/10.1038/s41558-018-0315-6

Nakashima, D. J., K. G. McLean, H. D. Thulstrup, A. R. Castillo, and J. T. Rubis. 2012. Weathering uncertainty: traditional knowledge for climate change assessment and adaptation. UNESCO, Paris, France, and UNU, Darwin, Australia. [online] URL: https://unesdoc.unesco.org/ark:/48223/pf0000216613

Nelson, M. P., and J. B. Callicott. 2008. The wilderness debate rages on: continuing the great new wilderness debate. University of Georgia Press, Athens, Georgia, USA.

Pascua, P., H. McMillen, T. Ticktin, M. Vaughan, and K. B. Winter. 2017. Beyond services: a process and framework to incorporate cultural, genealogical, place-based, and indigenous relationships in ecosystem service assessments. Ecosystem Services 26:465-475. https://doi.org/10.1016/j.ecoser.2017.03.012

Poe, M. R., J. Donatuto, and T. Satterfield. 2016. "Sense of place": human wellbeing considerations for ecological restoration in Puget Sound. Coastal Management 44:409-426. https://doi. org/10.1080/08920753.2016.1208037

Poepoe, K. K., P. K. Bartram, and A. M. Friedlander. 2003. The use of traditional Hawaiian knowledge in the contemporary management of marine resources. Fisheries Center Research Reports 11(1):328-339.

Prellezo, R., and R. Curtin. 2015. Confronting the implementation of marine ecosystem-based management within the Common Fisheries Policy reform. Ocean and Coastal Management 117:43-51. https://doi.org/10.1016/j.ocecoaman.2015.03.005

Price, M. R., and R. J. Toonen. 2017. Scaling up restoration efforts in the Pacific Islands: a call for clear management objectives, targeted research to minimize uncertainty, and innovative solutions to a wicked problem. Pacific Science 71(4):391-399. https://doi.org/10.2984/71.4.1

Reyes-García, V., Á. Fernández-Llamazares, P. McElwee, Z. Molnár, K. Öllerer, S. J. Wilson, and E. S. Brondizio. 2019. The contributions of Indigenous peoples and local communities to ecological restoration. Restoration Ecology 27(1):3-8. https://doi. org/10.1111/rec.12894

Robbins, P., A. Chhatre, and K. Karanth, 2015. Political ecology of commodity agroforests and tropical biodiversity. Conservation Letters 8(2):77-85. https://doi.org/10.1111/conl.12169 
Rodriguez, J. P., K. M. Rodriguez-Clark, J. E. M. Baillie, N. Ash, J. Benson, T. Boucher, C. Brown, N. D. Burgess, B. Collen, M. Jennings, D. A. Keith, E. Nicholson, C. Revenga, B. Reyers, M. Rouget, T. Smith, M. Spalding, A. Taber, M. Walpole, I. Zager, and T. Zamin. 2011. Establishing IUCN Red List criteria for threatened ecosystems. Conservation Biology 25:21-29. https:// doi.org/10.1111/j.1523-1739.2010.01598.x

Ross, A., K. P. Sherman, J. G. Snodgrass, H. D. Delcore, and R. Sherman. 2011. Indigenous peoples and the collaborative stewardship of nature: knowledge binds and institutional conflicts. Left Coast, Walnut Creek, California, USA. https://doi. org/10.4324/9781315426617

Society for Ecological Restoration (SER). 2004. The SER international primer on ecological restoration. Society for Ecological Restoration International, Washington, D.C., USA. [online] URL: https://cdn.ymaws.com/www.ser.org/resource/ resmgr/custompages/publications/ser publications/ser primer.pdf

Schröter, M., E. H. van der Zanden, A. P. E. van Oudenhoven, R. P. Remme, H. M. Serna-Chavez, R. S. De Groot, and P. Opdam. 2014. Ecosystem services as a contested concept: a synthesis of critique and counter-arguments. Conservation Letters 7 (6):514-523. https://doi.org/10.1111/conl.12091

Singleton, S. 2009. Native people and planning for marine protected areas: how "stakeholder" processes fail to address conflicts in complex, real-world environments. Coastal Management 37(5):421-440. https://doi.org/10.1080/08920750902954072

Smith, L. T. 2013. Decolonizing methodologies: research and indigenous peoples. Zed, London, UK.

Smith, L. T. 2015. Kaupapa Māori research - some Kaupapa Māori principles. Pages 46-52 in L. Pihama, S.-J Tiakiwai, and K. Southey, editors. Kaupapa Rangahau: a reader. A collection of readings from the Kaupapa Rangahau workshops series. Te Kotahi Research Institute, Hamilton, New Zealand. [online] URL: https://researchcommons.waikato.ac.nz/bitstream/handle/10289/11738/ Kaupapa\%20Rangahau\%20-\%20A\%20Reader 2nd\%20Edition. pdf? sequence $=7 \&$ is Allowed $=\mathrm{y}$

Soulé, M. E. 1985. What is conservation biology? BioScience 35:727-734. https://doi.org/10.2307/1310054

Sterling, E. J., C. Filardi, A. Toomey, A. Sigouin, E. Betley, N. Gazit, J. Newell, S. Albert, D. Alvira, N. Bergamini, M. Blair, D. Boseto, K. Burrows, N. Bynum, S. Caillon, J. E. Caselle, J. Claudet, G. Cullman, R. Dacks, P. B. Eyzaguirre, S. Gray, J. Herrera, P. Kenilorea, K. Kinney, N. Kurashima, S. Macey, C. Malone, S. Mauli, J. McCarter, H. McMillen, P. Pascua, P. Pikacha, A. L. Porzecanski, P. de Robert, M. Salpeteur, M. Sirikolo, M. H. Stege, K. Stege, T. Ticktin, R. Vave, A. Wali, P. West, K. B. Winter, and S. D. Jupiter. 2017. Biocultural approaches to well-being and sustainability indicators across scales. Nature Ecology and Evolution 1(12):1798-1806. https://doi.org/10.1038/s41559-017-0349-6

Sterling, E. J., P. Pascua, A. Sigouin, N. Gazit, L. Mandle, E. Betley, J. Aini, S. Albert, S. Caillon, J. E. Caselle, S. H. Cheng, J. Claudet, R. Dacks, E. S. Darling, C. Filardi, S. D. Jupiter, A. Mawyer, M. Mejia, K. Morishige, W. Nainoca, J. Parks, J. Tanguay, T. Ticktin, R. Vave, V. Wase, S. Wongbusarakum, and
J. McCarter. 2020. Creating a space for place and multidimensional well-being: lessons learned from localizing the SDGs. Sustainability Science 15(4):1129-1147. https://doi. org/10.1007/s11625-020-00822-w

Summers, C. C. 1964. Hawaiian fishponds. Bishop Museum Press, Honolulu, Hawai'i, USA.

Tengö, M., R. Hill, P. Malmer, C. M. Raymond, M. Spierenburg, F. Danielsen, T. Elmqvist, and C. Folke. 2017. Weaving knowledge systems in IPBES, CBD and beyond - lessons learned for sustainability. Current Opinion in Environmental Sustainability 26:17-25. https://doi.org/10.1016/j.cosust.2016.12.005

Terborgh, J. 2004. Requiem for nature. Island, Washington, D.C., USA.

Tipa, G., and R. Welch. 2006. Co-management of natural resources: issues of definition from an Indigenous community perspective. Journal of Applied Behavioral Science 42(3):373-391. https://doi.org/10.1177/0021886306287738

United Nations Food and Agriculture Organization (FAO). 2016. Free prior and informed consent: an indigenous peoples' right and a good practice for local communities. United Nations Food and Agriculture Organization, Rome, Italy. [online] URL: http://www. fao.org/3/a-i6190e.pdf

Wilder, B. T., C. O’Meara, L. Monti, and G. P. Nabhan. 2016. The importance of Indigenous knowledge in curbing the loss of language and biodiversity. BioScience 66(6):499-509. https://doi. org/10.1093/biosci/biw026

Wilshusen, P. R., S. R. Brechin, C. L. Fortwangler, and P. C. West. 2002. Reinventing a square wheel: critique of a resurgent "protection paradigm" in international biodiversity conservation. Society and Natural Resources 15:17-40. https://doi. org/10.1080/089419202317174002

Winter, K. B., K. Beamer, M. B. Vaughan, A. M. Friedlander, M. Kido, A. N. Whitehead, M. K. H. Akutagawa, N. Kurashima, M. P. Lucas, and B. Nyberg. 2018b. The Moku system: managing biocultural resources for abundance within social-ecological regions in Hawai'i. Sustainability 10(10):3554. https://doi. org/10.3390/su10103554

Winter, K. B., N. K. Lincoln, F. Berkes. 2018a. The socialecological keystone concept: a quantifiable metaphor for understanding the structure, function, and resilience of a biocultural system. Sustainability 10(10):3294. https://doi. org/10.3390/su10093294

Winter, K. B., N. K. Lincoln, F. Berkes, R. A. Alegado, N. Kurashima, K. Frank, P. Pascua, Y. M. Rii, F. Reppun, I. S. S. Knapp, et al. 2020a. Ecomimicry in Indigenous resource management: optimizing ecosystem services to achieve resource abundance with examples from Hawai i. Ecology and Society 25 (2):26. https://doi.org/10.5751/es-11539-250226

Winter, K. B., and M. Lucas. 2017. Spatial modeling of socialecological management zones of the Ali $i$ era on the island of Kaua ' $i$ with implications for large-scale biocultural conservation and forest restoration efforts in Hawai'i. Pacific Science 71:457-477. https://doi.org/10.2984/71.4.5 
Winter, K. B., T. Ticktin, and S. A. Quazi. 2020b. Biocultural restoration in Hawai i also achieves core conservation goals. Ecology and Society 25(1):26. https://doi.org/10.5751/ES-11388-250126

Yaffee, S. L., and J. M. Wondolleck. 2010. Collaborative ecosystem planning processes in the United States: evolution and challenges. Environments: A Journal of Interdisciplinary Studies 31(2):59-72.

Zimmerer, K. S. 2006. Globalization and new geographies of conservation. University of Chicago Press, Chicago, Illinois, USA. 